\title{
Optimize 2,4-D concentration and callus induction time enhance callus proliferation and plant regeneration of three rice genotypes
}

\author{
NONO CARSONO ${ }^{1, \bullet}$, ENDAH JUWENDAH ${ }^{2}$, LIBERTY $^{3}$, SANTIKA SARI ${ }^{1}$, FARIDA DAMAYANTI $^{1}$, \\ MEDDY RACHMADI ${ }^{1}$ \\ ${ }^{1}$ Laboratory of Plant Breeding, Faculty of Agriculture, Universitas Padjadjaran. Jl. Raya Bandung-Sumedang Km 21, Sumedang 45363, West Java, \\ Indonesia. Tel./fax.: +62-22-84288890, `email: n.carsono@unpad.ac.id. \\ ${ }^{2}$ Program of Agrotechnology, Faculty of Agriculture, Universitas Padjadjaran. Jl. Raya Bandung-Sumedang Km 21, Sumedang 45363, West Java, \\ Indonesia \\ ${ }^{3}$ Department of Agrotechnology, Faculty of Science and Technology, Universitas Islam Negeri Sunan Gunung Djati. Jl. A.H. Nasution No. 105, Cibiru, \\ Bandung 40614, West Java, Indonesia
}

Manuscript received: 7 March 2021. Revision accepted: 4 June 2021

\begin{abstract}
Carsono N, Juwendah E, Liberty, Sari S, Damayanti F, Rachmadi M. 2021. Optimize 2,4-D concentration and callus induction time enhance callus proliferation and plant regeneration of three rice genotypes. Biodiversitas 22: 2555-2560. The development of callus in the course of transgenic rice avoids the somaclonal variants. To obtain a high number of normal phenotypes and a low number of somaclonal variants requires an appropriate 2,4-D concentration. In this study, we obtained the best callus induction time and a high number of green plant regeneration for three responsive rice genotypes on different 2,4-D concentrations in NB5 medium. The mature seeds of rice embryos were used as explants. A completely randomized factorial design was applied with four levels of 2,4-D concentrations ( $0,1,3$, and $5 \mathrm{ppm}$ ), two levels of induction time (one and two weeks), and three rice genotypes (cv. Fatmawati, Nipponbare, and Kitake). The study revealed that there was no interaction effect among genotype, 2,4-D concentration, and callus induction time. Three rice genotypes performed best in callus proliferation and regeneration. One-week callus induction time showed higher callus growth capacity (CGC) as compared to two-week callus induction time. Shoot regeneration capacity (SRC) was independently affected by genotype as well as by callus induction time. The interaction effect between 2,4-D concentration and callus induction time was observed on plant regeneration capacity (PRC). Without the addition of 2,4-D and 1 ppm of 2,4-D, the green plant regeneration capacity (GRC) was comparatively higher. Addition of 2,4-D showed a significant effect, especially at the plant regeneration stage. We found that one-week callus induction was the best treatment for callus proliferation and plant regeneration. We recommend the use of one-week callus induction and $1 \mathrm{ppm}$ of 2,4-D for rice callus proliferation (sub-culture) and subsequent plant regeneration.
\end{abstract}

Keywords: Green plant regeneration, in vitro culture, somaclonal variants, subculture, rice

Abbreviations: CGC: callus growth capacity; CPC: callus proliferation capacity; GRC: green plant regeneration capacity; PRC: plant regeneration capacity; SRC: shoot regeneration capacity

\section{INTRODUCTION}

Genetic transformation facilitates the transfer of gene (s) controlling desirable trait (s) from unrelated plants or even other organisms that are difficult or impossible to attain in conventional breeding. The gene transformation method has demonstrated numerous important opportunities in the genetic improvement of rice (Jiang et al. 2016). This method has been proven in introducing some important genes controlling the important traits of rice such as resistance to insect pests (Yang et al. 2011), fungi (Maeda et al. 2019), bacteria (Mukhtar and Hasnain 2018), and virus (Ma et al. 2011) as well as to abiotic stresses, such as drought (Gao et al. 2011; Tang et al. 2019), salinity (Guo et al. 2016; Tang et al. 2019), and cold (Sato et al. 2011; Ma et al. 2015).

Rice genetic transformations require an efficient and reproducible of the in vitro culture system (Krishnan et al. 2013; Din et al. 2016). Optimization of in vitro culture system will support production of regenerable embryonic callus as a target tissue for rice genetic transformation. Callus or mass of undifferentiated cells, are excellent sources for in vitro regeneration and production of transgenic rice (Carsono and Yoshida 2008; Wada et al. 2009). Several studies on the development of efficient in vitro culture system in rice i.e., from callus induction, multiplication, and plant regeneration, have been previously reported (Carsono and Yoshida 2006; Din et al. 2016; Mostafiz and Wagiran 2018). However, limited reports have been done to shorten the time of callus induction, which is considered one of the main factors that contribute to the occurrence of somaclonal variations (Sahoo et al. 2011). This is because transgenic rice with somaclonal variations will hinder the evaluation and disturb the risk assessment of transgenic rice plants. The variant also makes more efforts to select desired transgenic rice lines from huge number of transformants derived from embryogenic callus cells.

Regenerable embryonic calluses for rice transformation are mostly produced from mature seeds (Carsono and 
Yoshida 2006; Miroshnichenko et al. 2016) which are convenient and available throughout the year. In rice, genotypic differences in in vitro regeneration capacity depend on their genetic background and their interaction with the culture media (Upadhyaya et al. 2015). Meanwhile, various media have been applied for rice callus induction and plant regeneration, such as MS, CI, D1, NB5, and L3 (Carsono and Yoshida 2006; Joya et al. 2019). However, NB5 is the most suitable medium for callus induction concerning its high nitrogen elements which could accelerate morphogenesis of the callus. The NB5 medium has been proven to be efficient and highly suitable for callus induction, proliferation and plant regeneration as reported by some researchers (Poeaim et al. 2016; Poraha et al. 2016). Besides media, the type of growth hormones (Din et al. 2016; Mostafiz and Wagiran 2018) significantly affects the successfulness of callus induction, proliferation, and plant regeneration.

In general, plant growth regulator such as 2,4-D (Dichlorophenoxyacetic acid) is well-known as one of plant growth regulators which help stimulate the optimum embryogenic callus proliferation and growth, although it varies according to the type of explants and combinations of media and concentration of the growth hormones, especially auxin. On the other hand, the genotype also plays important role in callus induction and plant regeneration (Mostafiz and Wagiran 2018). However, some of the abovementioned studies are only focused on the effect of genotype, and various concentrations of 2,4-D for callus induction (Ahmad et al. 2013; Mostafiz and Wagiran 2018) and plant regeneration (Upadhyaya et al. 2015; Azizah et al. 2017). Here, we studied the optimization of the growth hormones and time of callus induction on plant regeneration capacity of three responsive genotypes. The effect of callus induction time for previously reported three responsive rice genotypes i.e., Fatmawati (indica; Carsono and Yoshida 2006; Yunita et al. 2012), Nipponbare (japonica; Carsono and Yoshida, 2008), and Kitaake (japonica; Puhan and Siddiq 2013) on callus proliferation and plant regeneration on various concentration of 2,4-D in NB5 medium was examined.

\section{MATERIALS AND METHODS}

Mature healthy dehusked seeds of cv. Fatmawati (indica subspecies), Kitake, and Nipponbare (both japonica subspecies) were soaked in $70 \%$ ethanol for 3 min. followed by $2.5 \%$ sodium hypochlorite for $40 \mathrm{~min}$. with gently shaking and rinsed thoroughly with sterile distilled water five times. Thirty dehusked seeds per rice variety were cultured and replicated two times. The seeds were cultured in the bottle contained $10 \mathrm{ml}$ of callus induction media (NB5). The cultures were incubated in Growth Chamber with dark condition at $27{ }^{\circ} \mathrm{C}$ for two different callus induction times, i.e., one week ( 7 days) and two weeks (14 days). NB5 medium was added with $3 \mathrm{mg}$ $\mathrm{L}^{-1}$ 2,4-D (Carsono and Yoshida 2006), $8 \mathrm{~g}$ of agar, $0.1 \mathrm{~g}$ of Myo-inositol, $30 \mathrm{~g}$ of sucrose, and $100 \mathrm{ml} \mathrm{L}^{-1}$ of fresh coconut water. Five calluses per culture bottle were grown and incubated in the dark condition at $27^{\circ} \mathrm{C}$ for 7 days and 14 days (depended on its treatment).

The NB5 medium was used for callus proliferation (subculture) with addition of with $2 \mathrm{mg} \mathrm{L}^{-1}$ of BA, $8 \mathrm{~g}$ of agar, $100 \mathrm{ml} . \mathrm{L}^{-1}$ of coconut water, $0.1 \mathrm{~g}$ of Myo-inositol, $0.5 \mathrm{~g}$ of L-Proline, $0.5 \mathrm{~g}$ of L-Glutamine, $30 \mathrm{~g}$ of Maltose, and various concentrations of 2,4-D i.e., 0 ppm, 1 ppm, 3 $\mathrm{ppm}$, and $5 \mathrm{ppm}$. Calluses were incubated in the dark condition for 14 days at $27^{\circ} \mathrm{C}$. In plant regeneration stage, NB5 medium was added with $12 \mathrm{~g}$ of agar, $100 \mathrm{ml} \mathrm{L}^{-1}$ of coconut water, $0.1 \mathrm{~g}$ of Myo-inositol, $0.5 \mathrm{mg} \mathrm{L}^{-1}$ of NAA, $0.5 \mathrm{mg} \mathrm{L}^{-1}$ of IAA (Carsono and Yoshida 2006), $0.5 \mathrm{~g}$ of LProline, $0.5 \mathrm{~g}$ of L-Glutamine, $3 \mathrm{mg} \mathrm{L}^{-1}$ of Kinetin, $0.8 \mathrm{~g}$ of Casein Hydrolysate, $3 \mathrm{mg} \mathrm{L}^{-1}$ of BA and $30 \mathrm{~g}$ of Maltose. The $\mathrm{pH}$ of all media was adjusted to 5.8 before sterilization by autoclaving at temperature of $121^{\circ} \mathrm{C}$ for $30 \mathrm{~min}$. at 15 psi of pressure. Sub-cultured calluses with $5-10 \mathrm{~mm}$ in diameter were then transferred into bottle containing $10 \mathrm{ml}$ regeneration medium. Calluses were regenerated for 3-5 weeks in 8 hours dark condition and 16 hours light condition in the growth chamber (JSR: model JSPC-200C). For root induction, MS medium was used with addition of $30 \mathrm{~g} \mathrm{~L}^{-1}$ of Sucrose, $8 \mathrm{~g} \mathrm{~L}^{-1}$ of agar, and $0.1 \mathrm{~g} \mathrm{~L}^{-1}$ of Myoinositol. Regenerated shoots, over $2 \mathrm{~cm}$ in height, were transferred into plant growth regulator-free MS medium. After the seedling height reached about $10 \mathrm{~cm}$, the green plants were transferred into soil medium and grown in the greenhouse for acclimatization and further assessment.

The experiment was arranged in randomized factorial design. Genotypes (Fatmawati, Kitaake, and Nipponbare), 2,4-D concentrations in sub-culture ( 0 ppm, 1 ppm, 3 ppm, and $5 \mathrm{ppm}$ ), and callus induction time (one and two weeks) were considered as factors. At the sub-culture stage, two variables i.e., (i) callus proliferation capacity (CPC in \%) and (i) callus growth capacity (CGC in $\mathrm{mm}^{2}$ ) were observed. Three variables were observed at plant regeneration stage, i.e., (i) shoot-regeneration capacity (SRC in \%); (ii) plant regeneration capacity (PRC in \%); and (iii) green plant regeneration capacity (GRC). All variables were calculated based on Carsono and Yoshida (2006) formulas. Data were analyzed by using analysis of variance (ANOVA). Post-hoc analysis was done using Duncan's multiple range test (DMRT) for all variables. All calculations were performed by using SPSS ver. 22 .

\section{RESULTS AND DISCUSSION}

Overall analysis revealed that there was no significant interaction among three factors (genotype, concentration of 2,4-D, and callus induction time) for all five traits (CPC, CGC, SRC, PRC, GRC) in proliferation and plant regeneration stages (Table 1). There was no significant difference in callus proliferation capacity (CPC) for all factors in the proliferation phase while CGC was independently affected only by different times of callus induction. Three rice genotypes showed equality in CPC performance. 
Table 1. Analysis of variance for callus proliferation (CPC, CGC) and plant regeneration (SRC, PRC, GRC)

\begin{tabular}{|c|c|c|c|c|c|c|}
\hline Source of variation & df & $\begin{array}{c}\text { CPC } \\
(\%) \\
\end{array}$ & $\begin{array}{c}\text { CGC } \\
\left(\mathbf{m m}^{2}\right)\end{array}$ & $\begin{array}{c}\text { SRC } \\
(\%)\end{array}$ & $\begin{array}{c}\text { PRC } \\
(\%)\end{array}$ & $\begin{array}{c}\text { GRC } \\
(\%)\end{array}$ \\
\hline Genotype (G) & 2 & $7.49^{\mathrm{ns}}$ & $472.21^{\mathrm{ns}}$ & $47.20 * *$ & $9.20^{\mathrm{ns}}$ & $17.07^{\mathrm{ns}}$ \\
\hline Concentration of $2,4-\mathrm{D}(\mathrm{C})$ & 3 & $8.46^{\mathrm{ns}}$ & $183.86^{\mathrm{ns}}$ & $22.46^{\mathrm{ns}}$ & $30.66 * *$ & $31.59 * *$ \\
\hline Callus induction time $(\mathrm{T})$ & 1 & $0.02^{\mathrm{ns}}$ & $1000.10 *$ & $43.87 * *$ & $46.29 * *$ & $0.72^{\mathrm{ns}}$ \\
\hline $\mathrm{G} \times \mathrm{C}$ & 6 & $1.54^{\mathrm{ns}}$ & $206.61^{\mathrm{ns}}$ & $8.62^{\mathrm{ns}}$ & $9.62^{\mathrm{ns}}$ & $12.59^{\mathrm{ns}}$ \\
\hline $\mathrm{G} \times \mathrm{T}$ & 2 & $7.71^{\mathrm{ns}}$ & $526.85^{\text {ns }}$ & $2.35^{\mathrm{ns}}$ & $6.70^{\mathrm{ns}}$ & $3.49^{\mathrm{ns}}$ \\
\hline $\mathrm{C} \times \mathrm{T}$ & 3 & $1.11^{\mathrm{ns}}$ & $302.62^{\mathrm{ns}}$ & $5.03^{\mathrm{ns}}$ & $33.54 * *$ & $33.76^{\mathrm{ns}}$ \\
\hline $\mathrm{G} \times \mathrm{C} \times \mathrm{T}$ & 6 & $2.25^{\mathrm{ns}}$ & $275.56^{\mathrm{ns}}$ & $5.86^{\mathrm{ns}}$ & $4.73^{\mathrm{ns}}$ & $7.09^{\mathrm{ns}}$ \\
\hline Residual & 24 & 4.99 & $179.69^{\mathrm{ns}}$ & 7.99 & 4.25 & 14.28 \\
\hline Total & 47 & 4.29 & $248.16^{\mathrm{ns}}$ & 10.73 & 9.76 & 14.86 \\
\hline
\end{tabular}

Note: Data show means square value. CPC: Callus Proliferation Capacity; CGC: Callus-Growth Capacity; SRC: Shoot-Regeneration Capacity; PRC: Plant Regeneration Capacity; GRC: Green Plant Regeneration Capacity. The formulas to calculate all the variables were based on Carsono and Yoshida (2006). ns: non-significant, *: significant at $\mathrm{p}=0.05$, **: significant at $\mathrm{p}=0.01$.

Table 2. Comparison for 2,4-D concentration and callus induction time on plant regeneration capacity

\begin{tabular}{lcccc}
\hline \multirow{2}{*}{$\begin{array}{l}\text { Concentration } \\
\text { of 2,4-D }\end{array}$} & \multicolumn{3}{c}{ Plant regeneration capacity (\%) } \\
\cline { 2 - 5 } & $\begin{array}{c}\text { One week of callus } \\
\text { induction }\end{array}$ & \multicolumn{2}{c}{$\begin{array}{c}\text { Two-week of } \\
\text { callus induction }\end{array}$} \\
\hline $0 \mathrm{ppm}$ & 83.33 & $\mathrm{~A}$ & 77.78 & $\mathrm{~A}$ \\
& $\mathrm{a}$ & $\mathrm{a}$ & $\mathrm{a}$ & \\
$1 \mathrm{ppm}$ & 61.11 & $\mathrm{AB}$ & 66.67 & $\mathrm{~A}$ \\
& $\mathrm{a}$ & & $\mathrm{a}$ & \\
$3 \mathrm{ppm}$ & 38.89 & $\mathrm{~B}$ & 55.55 & $\mathrm{~A}$ \\
& $\mathrm{a}$ & & $\mathrm{a}$ & \\
$5 \mathrm{ppm}$ & 5.55 & $\mathrm{C}$ & 72.22 & $\mathrm{~A}$ \\
& $\mathrm{~b}$ & & $\mathrm{a}$ & \\
\hline
\end{tabular}

Note: Data are mean of two replications, each with 5 clusters of callus. Numbers followed by the same capital alphabet vertically (within callus induction time among 2,4-D concentration) and small alphabet horizontally (within 2,4-D concentration between callus induction time), are not significantly different by DMRT at 0.05 probability level.

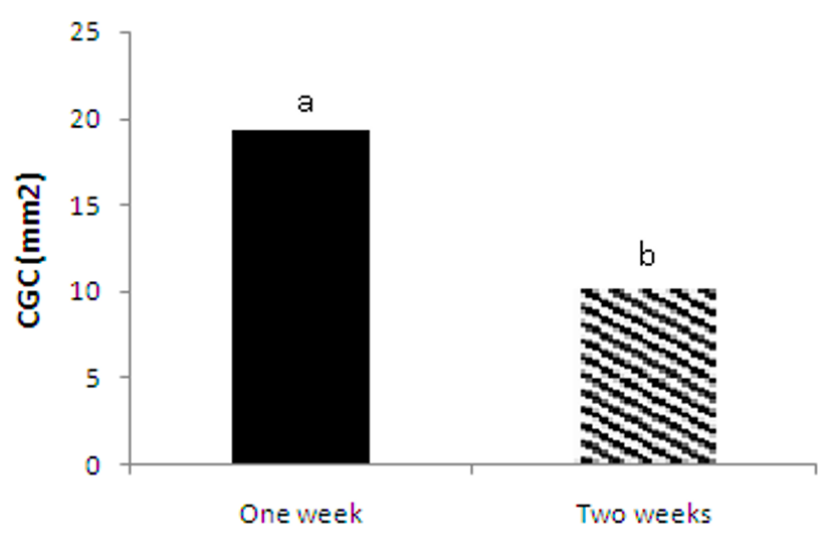

Figure 1. Comparison for callus induction time on the CGC in the proliferation phase (subculture). Note: values with the same alphabet show no difference by DMRT at 0.05 probability; CGC: callus growth capacity.
In the proliferation phase, the interaction effect among genotype, 2,4-D concentration and callus induction time was insignificant (Table 1). The effect was found only on callus induction time for CGC, which means that the callus induction time affected CGC, nor CFC. One week callus induction time showed higher CGC compared to two-week callus induction time (Figure 1). In the plant regeneration phase, SRC (shoot regeneration capacity) was independently affected by genotype and time of callus induction (Table 1). Genotype Kitaake and Fatmawati performed the best in SRC, meanwhile, Nipponbare showed the lowest SRC (Figure 2). In addition, one-week callus induction time resulted in higher SRC than two-week callus induction time (Figure 2).

In contrast, genotype did not significantly affect PRC and GRC (Table 1). Callus induction time contributed to generate a high variation in PRC (Table 1); meanwhile, concentration of 2,4-D independently accounted for the high variation in GRC and PRC. Application of 2,4-D at 0 ppm and $1 \mathrm{ppm}$ resulted in higher GRC than other 2,4-D concentrations (Figure 3). The interaction between concentration of 2,4-D and callus induction time was significant for PRC (Table 1).

The significant difference between one-week and twoweek callus induction on PRC only occurred on $5 \mathrm{ppm}$ of 2,4-D concentration, whereas two-week callus induction resulted in higher PRC (72.22 \%) than one-week callus induction $(5.55 \%)$ (Table 2). No significant differences were found on concentration of 2,4-D within two-week callus induction. Conversely, $5 \mathrm{ppm}$ of 2,4-D significantly resulted in the lowest PRC within one-week callus induction (Table 2). The treatment without addition of 2,4$\mathrm{D}$ during plant regeneration stage relatively showed higher PRC than the others, except with 1 ppm (Table 2). Generally, the application of lower 2,4-D concentrations in plant regeneration media resulted in high plant regeneration capacity in both one-week and two-week callus induction time. 


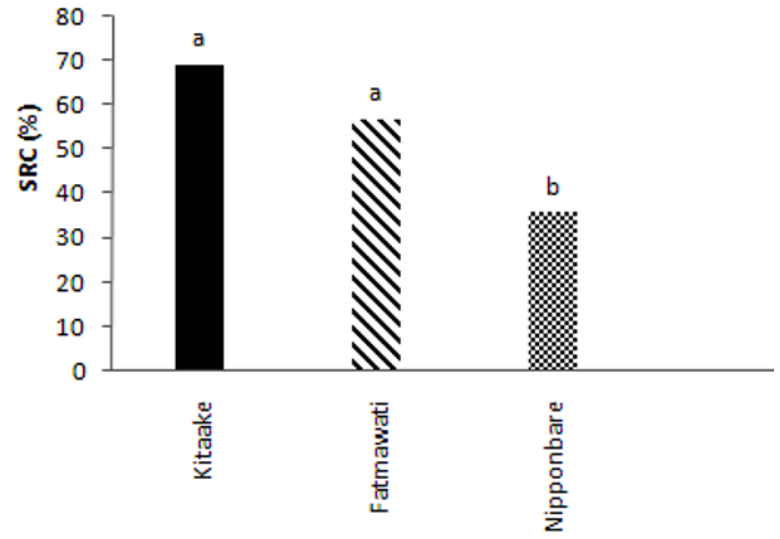

A

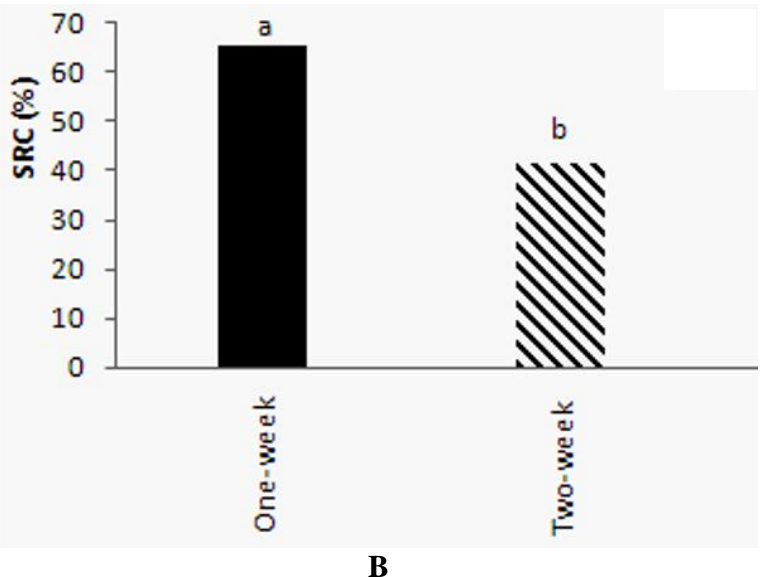

Figure 2. Comparison for genotype (A) and callus induction time (B) on the SRC (shoot regeneration capacity) in the plant regeneration stage. Notes: values with the same alphabet show no difference by DMRT at 0.05 probability

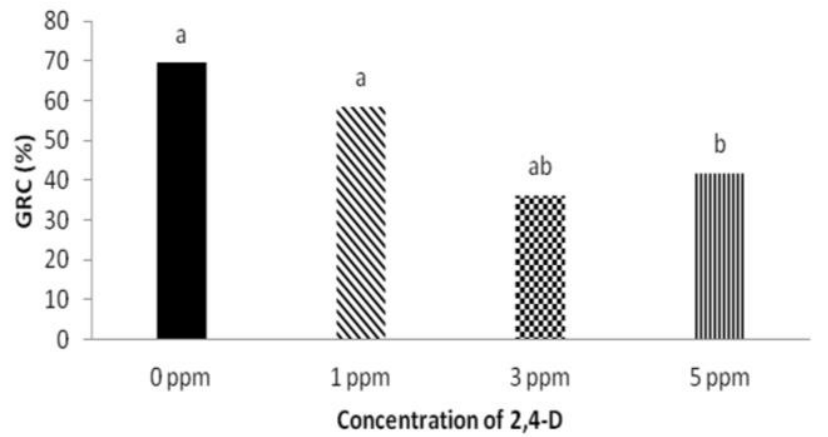

Figure 3. Comparison for the concentrations of 2,4-D on the green plant regeneration capacity (GRC). Notes: values with the same alphabet show no difference by DMRT at 0.05 probability

Green plant regeneration capacity (GRC) was affected independently by concentrations of 2,4-D (Table 1 ). The appearance of plantlets varied within the concentrations of 2,4-D. Without addition of 2,4-D and $1 \mathrm{ppm}$ of 2,4-D in plant regeneration media, the production of GRC was relatively higher (Figure 3 ).

\section{Discussion}

In vitro rice culture system is one of the major factors which hampers the success of application of genetic transformation and other biotechnological works, such as microspore or anther culture, micropropagation, embryo rescue, double haploid, plant cell culture for production of important secondary metabolite, and other in vitro culture efforts. Our study demonstrated the importance of callus induction time on callus proliferation, especially callus growth capacity, and 2,4-D concentration affects green plant regeneration.

Establishment of in vitro rice culture in terms of callus proliferation and plant regeneration will broadly open the success of application of genetic transformation for desirable genes for improving economical and agronomically important traits of rice plants. The previous studies showed that callus from tissue culture may induce variations (Bairu et al. 2011), known as somaclonal variations that hamper the application of in vitro culture to develop transgenic rice plants. In in vitro culture, callus produced through an in vitro culture system, is a good starting material for genetic transformation (Carsono and Yoshida 2008; Sahoo et al. 2011; Tran and Sanan-Mishra 2015; Mukhtar and Hasnain, 2018; Mohammed et al. 2019). Our study shows that optimization of the growth hormones application, in this case, 2,4-D, and callus induction time can reduce the somaclonal variations in terms of high number of green plant (plantlet) regeneration.

Three ways interaction among genotype, 2,4-D concentration and callus induction time was unrevealed in this present study. Three genotypes exhibited the same callus proliferation capacity, these due to Kitaake and Nipponbare (Puhan and Siddiq 2013) and Fatmawati (Carsono and Yoshida 2006) are considered to be highly responsive in in vitro culture. Furthermore, Kitaake was also reported to have a high callus regeneration rate, fast callus growth, and fast embryonic callus development ability with crumb, globular, and compact callus type (Sah et al. 2014). In addition to genetic factors, as described previously, non-genetic factors also affect the formation of callus and shoot regeneration i.e., age of explants (Hoque and Mansfield 2004) and culture condition (Husaini et al. 2011; Lardon and Geelen 2020). Although Ahmad et al. (2013) reported that 2,4-D is an essential element for callus proliferation, the different concentrations of 2,4-D showed the same effect on CPC and CGC. Probably, the endogenous auxins contained in the callus were enough to support callus proliferation and growth.

It was found that shorter callus induction time had a better effect on cell division and produced high proliferation cells (Carsono and Yoshida 2006), increasing CGC and SRC. Meanwhile, callus proliferation and plant regeneration depend on many factors, i.e., gene activity, meristematic cells, hormone level in the cell, and hormone sensitivity (Ezhova 2003). Among them, gene activity may influence or provide different expressions (Ezhova 2003; 
Abiri et al. 2016). Besides, the age of the mature seed also affects the formation of callus (Hoque and Mansfield, 2004).

The best CGC (Figure 1) and SRC (Figure 2) were found at one-week callus induction. According to Manimaran et al. (2013), this is noted that young calluses had higher capacity of callus development into whole tissue compared to aged calluses. This is because young callus contains high amount of actively dividing cells, then they are more responsive to a callus initiation program, in this case, callus growth and shoot development.

Ikeuchi et al. (2016) also reported that among the different factors influencing callus induction and regeneration, genotype and nutrient media composition are two major factors that decide the fate of in vitro raised culture. Favorable hormone balances may exist not only in growth media but also in calluses. Endogenous hormone production may be induced by various exogenous hormone and stimulating treatments (Ikeuchi et al. 2016; Lardon and Geelen 2020). It is presumed that exogenic and endogenic growth hormones at relatively earlier subculture time would support the shoot development of callus.

Higher 2,4-D concentration (above $4.02 \mathrm{mg} \mathrm{L}^{-1}$ for 48 h) was reported to decrease mitotic index, which inhibits cell division (Ozkul et al. 2016). Therefore, for initiating the cell division, lower concentration of 2,4-D was applied, while high concentration was applied for callus induction and subculture stages because it was important due to the residual effect within culture media. Residual effect of 2,4$\mathrm{D}$ occurred when exogenic auxin was remained or not added in the culture media (Hazubska-Przybył et al. 2020; Wójcik et al. 2020). This result suggests that excessive addition of 2,4-D will reduce the callus development rate due to in vitro totipotency is affected by the genes controlling the level of hormones in the cells and threshold of sensitivity to hormones (Ezhova 2003).

Overall experiments, two genotypes i.e., Kitaake (japonica subspecies) and Fatmawati (indica) used in this experiment showed similar responses in almost all the variables observed in both stages, callus proliferation and plant regeneration. It is proven that Fatmawati, Kitaake, and Nipponbare were responsive genotypes in callus proliferation and plant regeneration. Addition of 2,4-D showed significant effect, especially at plant regeneration stage. The most interesting result was one-week callus induction time showed the best result in both stages. Finally, to reduce the somaclonal variation, we recommend a short time (one week) and $1 \mathrm{ppm}$ of 2,4-D for rice callus proliferation (sub-culture) and plant regeneration for the case of these three rice genotypes. The in vitro rice culture protocol developed from this study for callus proliferation and plant regeneration, will be useful for genetic transformation and other biotechnological works. This protocol will also be useful in order to minimize the occurrence of somaclonal variants which is a major concern in the development of transgenic rice plants with many valuable traits.

\section{ACKNOWLEDGEMENTS}

The authors wish to acknowledge Dr. Buang Abdullah, Indonesian Center for Rice Research for providing cv. Fatmawati's seeds and Directorate General of Higher Education, Indonesia for providing a Graduate Research Grant Program.

\section{REFERENCES}

Abiri R, Maziah M, Shaharuddin NA, Yusof ZN, Atabaki N, Hanafi MM, Sahebi M, Azizi P, Kalhori N, Valdiani A. 2016. Enhancing somatic embryogenesis of Malaysian rice cultivar MR219 using adjuvant materials in a high-efficiency protocol. Intl J Environ Sci Technol 14: 1091-1108. DOI: 10.1007/s13762-016-1221-y.

Ahmad FI, Johan NS, Wagiran A. 2013. Effect of 2,4-D on embryogenic callus induction of Malaysian indica rice (Oryza sativa L.) cultivars MR123 and MR127. Jurnal Teknologi 64 (2): 75-78. DOI: 10.11113/jt.v64.2048.

Azizah KA, Restanto DP, Sugiharto B. 2017. Enhancement of regeneration efficiency through optimization in callus induction media using 2,4-Dichlorophenoxyacetic acid in indica rice (Oryza sativa L. Var. Ciherang). Jurnal Ilmu Dasar 18 (2): 91-98. [Indonesian]

Bairu MW, Aremu AO, Staden JV. 2011. Somaclonal variation in plants: Causes and detection methods. Plant Growth Regul 63: 147-173. DOI: 10.1007/s10725-010-9554-x.

Carsono N, Yoshida T. 2006. Plant regeneration capacity of calluses derived from mature seed of five Indonesian rice genotypes. Plant Prod Sci 9: 71-77. DOI: 10.1626/pps.9.71.

Carsono N, Yoshida T. 2008. Transient expression of green fluorescent protein in rice calluses: Optimization of parameters for Helios gene gun device. Plant Prod Sci 11: 88-95. DOI: 10.1626/pps.11.88.

Din AJM, Ahmad FI, Wagiran A, Rahmat AAZ, Sarmidi MR. 2016. Improvement of efficient in vitro regeneration potential of mature callus induced from Malaysian upland rice seed (Oryza sativa cv. Panderas). Saudi J Biol Sci 23 (1): S69-S77. DOI: 10.1016/j.sjbs.2015.10.022.

Ezhova TA. 2003. Genetic control of totipotency of plant cells in an in vitro culture. Russian J Develop Biol 34 (4): 197-204. DOI: 10.1023/A:1024940130511.

Gao T, Wu Y, Zhang Y, Liu L, Ning Y, Wang D, Tong H, Chen S, Chu C, Xie Q. 2011. OsSDIR1 overexpression greatly improves drought tolerance in transgenic rice. Plant Mol Biol 76: 145-156. DOI: 10.1007/s11103-011-9775-z.

Guo W, Chen T, Hussain N, Zhang G, Jiang L. 2016. Characterization of salinity tolerance of transgenic rice lines harboring HsCBL8 of wild Barley (Hordeum spontaneum) line from Qinghai-Tibet Plateau. Front Plant Sci 7: 1678. DOI: 10.3389/fpls.2016.01678.

Hazubska-Przybył T, Ratajczak E, Obarska A, Pers-Kamczyc E. 2020. Different roles of auxins in somatic embryogenesis efficiency in two Picea species. Intl J Mol Sci 21 (9): 3394. DOI: 10.3390/ijms21093394.

Hoque ME, Mansfield JW. 2004. Effect of genotype and explants age on callus induction and subsequent plant regeneration from root-derived callus of indica rice genotypes. Plant Cells Tiss Organ Cult 78: 217223. DOI: 10.1023/B:TICU.0000025640.75168.2d.

Husaini AM, Mercado JA, da Silva JAT, Schaart JG. 2011. Review of factors affecting organogenesis, somatic embryogenesis and Agrobacterium tumefaciens-mediated transformation of strawberry. Genes, Genomes and Genomics 5 (Special Issue 1): 1-11.

Lardon R, Geelen D. 2020. Natural variation in plant pluripotency and regeneration. Plants 9 (10): 1261. DOI: 10.3390/plants9101261.

Ikeuchi M, Ogawa Y, Iwase A, Sugimoto K. 2016. Plant regeneration: cellular origins and molecular mechanisms. Development 143: 14421451. DOI: $10.1242 /$ dev.134668.

Jiang SE, Xie L, Ramachandran S. 2016. Improving protein content and quality by over-expressing artificially synthetic fusion proteins with high lysine and threonine constituent in rice plants. Sci Rep 6: 34427. DOI: $10.1038 /$ srep34427

Joya SD, Sultana S, Ferdous J, Qayum MA, Hoque MQ. 2019. Response to callus induction and regeneration of newly released BRRI rice 
varieties. Bangladesh Rice J 23 (2): 17-25. DOI: 10.3329/brj.v23i2.48244.

Krishnan SR, Priya AM, Ramesh M. 2013. Rapid regeneration and ploidy stability of 'cv IR36' indica rice (Oryza sativa L.) confers efficient protocol for in vitro callus organogenesis and Agrobacterium tumefaciens mediated transformation. Bot Stud 54: 47. DOI 10.1186/1999-3110-54-47.

Maeda S, Dubouzet JG, Kondou Y, Jikumaru Y, Seo S, Oda K, Matsui M, Hirochika H, Mori M. 2019. The rice CYP78A gene BSR2 confers resistance to Rhizoctonia solani and affects seed size and growth in Arabidopsis and rice. Nat Sci Rep 9: 587. DOI: 10.1038/s41598-01837365-1.

Ma J, Song Y, Wu B, Jiang M, Li K, Zhu C, Wen F. 2011. Production of transgenic rice new germplasm with strong resistance against two isolations of rice stripe virus by RNA interference. Transgenic Res 20: 1367-1377. DOI: 10.1007/s11248-011-9502-1.

Ma Y, Dai X, Xu Y, Luo W, Zheng X, Zeng D, Pan Y, Lin X, Liu H, Wang W, Qian Q, Ge S, Chong K. 2015. COLD1 confers chilling tolerance in rice. Cell 160 (6): 1209-1221. DOI: 10.1016/j.cell.2015.01.046.

Manimaran P, Kumar GR, Reddy MR, Jain S, Rao TB, Mangrauthia SK, Sundaram RM, Ravichandran S, Balachandran SM. 2013. Infection of early and young tissues of Indica rice BPT 5204 enhances regeneration and transformation efficiency. Rice Sci 20 (6): 415-426. DOI: $10.1016 / \mathrm{S} 1672-6308(13) 60153-5$.

Miroshnichenko D, Chernobrovkina M, Dolgov S. 2016. Somatic embryogenesis and plant regeneration from immature embryos of Triticum timopheevii Zhuk. and Triticum kiharae Dorof. et Migusch, wheat species with G genome. Plant Cell Tiss Organ Cult 125: 495508. DOI: $10.1007 / \mathrm{s} 11240-016-0965-\mathrm{x}$.

Mohammed S, Samad AA, Rahmat Z. 2019. Agrobacterium-mediated transformation of rice: Constraints and possible solutions. Rice Sci 26 (3): 133-146. DOI: 10.1016/j.rsci.2019.04.001.

Mukhtar Z, Hasnain S. 2018. Optimization of particle bombardment conditions for rice (Oryza sativa L.). Pak J Agric Sci 55 (2): 271-278 DOI: 10.21162/PAKJAS/18.3678.

Mostafiz SB, Wagiran A. 2018. Efficient callus induction and regeneration in selected indica rice. Agronomy 8 (5): 77 . DOI: 10.3390/agronomy8050077.

Özkul M, Özel ÇA, Yüzbaşıŏlu D, Ünal F. 2016. Does 2,4 dichlorophenoxyacetic acid (2,4-D) induce genotoxic effects in tissuecultured Allium roots? Cytotechnology 68 (6): 2395-2405. DOI 10.1007/s10616-016-9956-3.

Poeaim A, Poeaim S, Poraha R, Pongjaroenkit S, Pongthongkam P. 2016. Optimization for callus induction and plant regeneration from mature seeds of Thai rice variety: Nam Roo (Oryza sativa $\mathrm{L}$ ) Bioengineer Biosci 45 (5): 95-99. DOI: 10.13189/bb.2016.040504.

Poraha A, Poeaim A, Pongjaroenkit S, Pongthongkam P. 2016. Callus induction and plant regeneration on optimization of the culture conditions in Jow Haw Rice (Oryza sativa L.). Intl J Agric Technol 12 (2): 241-248.

Puhan P, Siddiq EA. 2013. Protocol optimization and evaluation of rice varieties response to in vitro regeneration. Adv Biosci Biotechnol 4: 647-653. DOI: $10.4236 / \mathrm{abb} .2013 .45085$.

Sah SK, Kaur A, Sandhu JS. 2014. High frequency embryogenic callus induction and whole plant regeneration in japonica rice cv. Kitaake. $\mathrm{J}$ Rice Res 2: 2. DOI: 10.4172/jrr.1000125.

Sahoo KK, Tripathi AK, Pareek A, Sopory SK, Pareek SLS. 2011. An improved protocol for efficient transformation and regeneration of diverse indica rice cultivars. Plant Methods 7: 49. DOI: 10.1186/1746-4811-7-49.

Sato Y, Masuta Y, Saito K, Murayama S, Ozawa K. 2011. Enhanced chilling tolerance at the booting stage in rice by transgenic overexpression of the ascorbate peroxidase gene, OsAPXa. Plant Cell Rep 30: 399-406. DOI: 10.1007/s00299-010-0985-7.

Tang Y, Bao X, Zhi Y, Wu Q, Guo Y, Yin X, Zeng L, Li J, Zhang J, He W, Liu W, Wang Q, Jia C, Li Z, Liu K. 2019. Overexpression of a MYB family gene, OSMYB6, increases drought and salinity stress tolerance in transgenic rice. Front Plant Sci 10: 168. DOI: $10.3389 /$ fpls.2019.00168.

Tran TN, Sanan-Mishra N. 2015. Effects of antibiotics on callus regeneration during transformation of IR 64 rice. Biotechnol Rep 7: 143-149. DOI: 10.1016/j.btre.2015.06.004.

Upadhyaya G, Sen M, Roy A. 2015. In vitro callus induction and plant regeneration of rice (Oryza sativa L.) var. 'Sita', 'Rupali' and 'Swarna Masuri'. Asian J Plant Sci Res 5 (5): 24-27.

Wada Y, Carsono N, Anas, Tong L, Yoshida T. 2009. Genetic transformation of high molecular weight glutenin (Glu-1Dx5) to rice cv. Fatmawati. Plant Prod Sci 12 (3): 341-344. DOI: $10.1626 /$ pps. 12.341

Wójcik A, Wójcikowska B, Gaj MD. 2020. Current Perspectives on the auxin-mediated genetic network that controls the induction of somatic embryogenesis in plants. J Mol Sci 21 (4): 1333. DOI: 10.3390/ijms21041333.

Yunita R, Lestari EG, Dewi IS. 2012. Shoot regeneration of irradiated calluses of rice cv. Fatmawati. Berita Biologi 11 (3): 359-366. DOI: 10.14203/beritabiologi.v11i3.506. [Indonesian]

Yang Z, Chen H, Tang W, Hua H, Lin Y. 2011. Development and characterisation of transgenic rice expressing two Bacillus thuringiensis genes. Pest Manag Sci 67: 414-422. DOI: 10.1002/ps.2079 